\title{
5 Drifting Westward? East Germany and Integrated Europe
}

\author{
Maximilian Graf
}

In spring 1983, when the German Democratic Republic (GDR) faced acute danger of bankruptcy, Erich Honecker's critics in the East German leadership reported to Moscow that the general secretary of the Socialist Unity Party of Germany (Sozialistische Einheitspartei Deutschlands [SED]) considered the 'European Community to be way ahead of the CMEA'. In their view, his position was 'anti-communist, false, slanderous and has to be appropriately shattered through a proper appraisal of the history of the CMEA and a thorough exposure of the imperialist EC'. ${ }^{1}$ But this was only the tip of the iceberg. For some years they had complained about Honecker's economic policy, the growing dependence on the West and West Germany and, in their view, an increasingly ambivalent attitude towards the Soviet Union. Next to Honecker, the almost almighty SED secretary of economics, Günter Mittag, was the main target of their criticism. They even demanded his removal. Seeing no way of changing the course within the politburo, Honecker's critics hoped for action by the Communist Party of the Soviet Union (CPSU). ${ }^{2}$ Among them were politburo members Werner Krolikowski, Prime Minister Willi Stoph and, though to a varying degree, Minister of State Security Erich Mielke, who in the years of economic and financial crisis often backed Honecker's policy in Moscow. ${ }^{3}$ Within the GDR's ruling circles these back-channel critics stayed surprisingly silent and hardly ever openly opposed the political course. Regarding economics, opposition was instead voiced by experts. However, their criticism fell on deaf ears and economic policy was not changed throughout the Honecker era.

In comparison to other CMEA countries, the economic history of the GDR is especially well researched. It is well known who the economic decision-makers were, and internal conflicts have been studied in detail. At the macro level, economic decision-making was dominated by Honecker's 'small circle'. This consisted of the politburo members responsible for economic policy and the head of the State Planning Commission, Gerhard Schürer, whose influence declined in the Honecker era. Although officially out of office from 1973 to 1976, the most remarkable figure in this circle was Mittag, who also presided over the politburo's FRG Working Group. ${ }^{4}$ Foreign policy decision-making was centralised to, and at times even monopolised by, the secretary general and his closest advisors. Nevertheless, regarding dependence on the West and relations with the Federal Republic 
of Germany (FRG), it remains questionable whether Honecker's critics were right in accusing him of a westward drift or if this policy was more a result of the unresolvable paradoxes of the existence of the GDR.

Among the European socialist states, East Germany was a special case characterised by several particularities. Many of these were direct consequences of the division of Germany. While the more prosperous FRG became a permanent magnet for the East German population, the Soviet Union was the most important political and economic partner and controller when it came to the GDR's relations with the West. Therefore, Moscow and Bonn were the points of reference for the most exposed Warsaw Pact country. Historiography has established solid knowledge of the GDR's foreign relations, ${ }^{5}$ but a thorough analysis of East Germany's perceptions of the West and its dealings with it in the "long 1970s" is lacking. By combining often separated narratives on foreign policy and foreign trade, this chapter aims to broaden our understanding of the East German regime's rationale and actions by widening the perspective to a pan-European view.

The early 1970s brought not only a normalisation of German-German relations but also long-desired diplomatic recognition by the West and a sudden multiplication of international relations. Notwithstanding the centrality of the FRG in the East German concept of the West, this led to a far more pan-European approach than the common narrative centred on Bonn and Moscow suggests. Even though publicised SED policy documents only ranked the priority of the West after the socialist world and developing countries, the GDR devoted much energy to improving relations with it, especially with a view to reducing its dependency on the FRG. ${ }^{6}$ Although the GDR's pan-European policy extended to most countries on the continent, this chapter focuses on its foreign and economic policy towards the European Economic Community (EEC) and its member states. Apart from the FRG, France, Italy and the UK became preferred partners, though the smaller countries mattered as well. ${ }^{7}$ Although the GDR pursued a strictly bilateral approach in its relations with the West, it had to cope with the progress of European integration. While existing scholarship on the East German attitude to the EEC is mostly limited to perceptions of the integration process, ${ }^{8}$ this chapter investigates how the GDR dealt with the economic policies of the EEC and their repercussions on trade. The analysis is embedded in a broader account of how the East German elites perceived the role of Western Europe and the EEC in times of incipient globalisation, economic turbulence and détente.

What strategies did the East German regime develop to secure its goals against the challenge presented by the fact that long-desired international recognition and growing economic cooperation also resulted in dependencies and required at least some opening up? How did they change when the GDR faced growing economic problems towards the end of the decade? We know that many East German policies constituted little more than wishful thinking, but their intent was to make the existence of the GDR under SED rule permanent. Hence, the leadership aimed at demarcation, far more regarding West Germany than the rest of the West. The seemingly westward drift of the GDR in the Honecker era must be placed in its proper historical context by stressing continuities originating in the 1960s. Therefore, this chapter will first offer a summary of the European and German-German 
background. It will then examine the first half of the 1970s, a period of selfperceived success and confidence in which foreign and domestic political considerations shaped East German politics most. The third section will analyse the second half of the decade, when economic problems became more pressing and finally led to the debt crisis of the early 1980s. The conclusion emphasises how the East German way of surviving a severe economic crisis without fundamentally changing the failed economic policy was successful in the short term but contributed to the collapse of the regime in 1989.

\section{European and German-German background}

The East German long 1970s were decisively shaped by earlier developments, not only by the division of Germany but also the economic path(s) chosen. The industrialised East German territory was cut off from the broader economic area it belonged to until 1945 and lacked supplies of raw materials and the sales markets in which it was formerly embedded. Instead, it became a centrally planned economy integrated in the socialist bloc. The founding of two German states in 1949 was a result of the Cold War's division of Europe and was followed by two decades of mutual non-recognition. However, in the economic field, strong and beneficial bonds persisted. Intra-German trade became a unique specialty that developed out of exchanges between the occupation zones. It was regulated in 1951 through the indefinite Berlin agreement on trade between the currency zones of East and West Germany, which (with modifications) remained in force until German unification. The intentionally balanced exchange of goods was deducted in clearing units (Verrechnungseinheiten [VE]), with one VE equalling one deutsche mark (DM) and one GDR mark. Due to its nature, intra-German trade meant considerable economic advantages for the GDR, while the FRG pursued primarily, although not exclusively, political interests. There were tax benefits and no customs, and West Germany provided an interest-free technical loan covering the (anything but temporary) imbalances in the clearing account, the so-called swing. ${ }^{9}$

The founding of the EEC did not affect intra-German trade. In a protocol annexed to the Rome Treaties of 1957, the member states accepted the FRG's stance that trade between the two Germanies was domestic trade and did not require certificates of origin and was not subject to customs. Privileged access to the West German market made the GDR's economic relations with the West unique. While the other socialist states lacked this advantage and complained about it, the GDR defended it regardless of broader political goals. After an initial decline in the first half of the 1960s, due to the Störfreimachung policy aiming at a reduction of economic dependence on the FRG, the trade volume increased towards the end of the decade. This development was facilitated by easings that Bonn offered on investment loans and a more generous "swing". ${ }^{10}$

None of the Western countries recognised the GDR until the settling of GermanGerman relations with the Basic Treaty of 1972. Despite the absence of diplomatic relations, economic exchanges between East Germany and the West had never ceased, and they re-intensified in the mid-1960s. East Berlin's political elite regarded the improvement of economic relations as an instrument for achieving 
recognition. The first loan-financed investment deals with Western companies were intended to serve this purpose. In 1970, a large railway rolling stock order amounting to 800 million francs was placed in France. Paris enabled this deal by violating the EEC credit guidelines, which were changed a little later on French request. The next year, Mittag was invited to the French capital. East Berlin celebrated this as a major success, although it did not lead to any progress regarding recognition. ${ }^{11}$

The share of East German exports to the CMEA countries declined from $66.4 \%$ in 1965 to $59.5 \%$ in 1971 and the share of imports from $63.3 \%$ to $58.3 \%$. However, the impact of economic decisions taken for political purposes should not be overestimated. In fact, the West's increasing share in the GDR's foreign trade had basic economic reasons. The USSR and the other CMEA members were not willing or able to provide everything the industrialised East German economy needed to promote its competitiveness. For example, the production of machinery required new (Western) technology, and components needed to export to the socialist states had to be bought in the West. The CMEA Comprehensive Programme of 1971 did not facilitate the situation, as catching-up specialisation by the less developed member states reduced the sales markets in the East. In the West, East German products became less and less marketable. Terms of trade worsened both in the East and West, and increased exchanges with the West boosting the technology level of the East German economy seemed the only way out of this downward spiral. Nevertheless, the GDR was well integrated in the CMEA market, and modernisation through economic cooperation with the West always aimed to reduce dependence on the West and especially West Germany in the long run. As Ralf Ahrens states, 'Trade with capitalist countries was always a necessary evil to compensate the shortcomings of intra-COMECON trade and Eastern bloc economic coordination'. ${ }^{12}$

André Steiner has demonstrated that the New Economic System reform of the 1960s (which included some market elements, a very limited short-lived liberalisation of the foreign trade regime and a strategy of import-led growth labelled as a technology offensive) had remained within the concept of a centrally planned economy. It failed and was finally abandoned in 1970-71. The escalating number of large-scale investments exceeded the economic means of the GDR. One of the reasons why this was paralleled by a change of party leader in 1971 was internal and Soviet disagreement over the reforms and growing dependency (in the form of debts) on the West and West Germany. ${ }^{13}$

\section{The hopeful years: recognition, cooperation and welfare without opening}

In May 1971, the politburo ousted First Secretary Walter Ulbricht from power, elected Honecker as his successor, abolished the economic reforms and returned to strict central planning. Following the example of the CPSU, the eighth Party Congress of the SED later that year adopted the so-called Main Task, a socialist welfare policy concept that was later labelled Unity of Economic and Social Policy. This policy was expensive as it included subsidised prices, a housing programme 
and imports of consumer goods. The East German economy was never able to cover the costs. The State Planning Commission (headed by Schürer), central and foreign trade bankers (Grete Wittkowski, Horst Kaminsky, Helmut Dietrich, Werner Polze), Minister of Finance Siegfried Böhm and experts from academia (Helmut Koziolek, Otto Reinhold) immediately warned about the potential consequences of increasing debts. In later years their chorus was joined by the Ministry of State Security. Apart from the issue of debt, the agency of these economic elites is less visible than in other CMEA countries. Economic decisions were taken in Honecker's party-state small circle, and his rationale was to keep people satisfied (to the greatest possible extent). Hence, the policy remained unchanged even when the situation dramatically worsened from the mid-1970s onwards. ${ }^{14}$

Why did criticism fall on deaf ears for so many years? Against the background of the Polish workers' uprising in 1970 and incipient détente, the East German leadership truly believed that any worsening of living conditions was likely to destabilise the regime. Among the reasons for this are the socialisation of politicians in the interwar period, or more precisely Honecker's distrust of his own people, ${ }^{15}$ as well as the spectre of another people's uprising haunting the SED leadership since 1953. At least in retrospect, the belief that better living conditions would automatically lead to improved economic performance was wishful thinking. ${ }^{16}$ Although the policy was unaffordable in the long term, even the critical chief planner Schürer admitted in his memoirs that the loan-financed economic and social policy created a hopeful and more satisfied atmosphere in the first half of the 1970s, until it became clear that servicing the debts had turned into a serious problem. ${ }^{17}$

The rise of the Commercial Coordination division (Bereich Kommerzielle Koordinierung [KoKo]) operating outside the plan is proof of the leadership's acknowledgement that the economic policy did not work. Founded in 1966, KoKo was formally part of the Ministry of Foreign Trade, but in fact it was closely connected to the Ministry of State Security and under the control of the party's leading economic officials. The purposes of this institution, headed by Alexander Schalck-Golodkowski, were to earn convertible currency, make Western trade more flexible and solve financial crises. It gained importance throughout the $1970 \mathrm{~s}$, and in the 1980s KoKo organised Western and intra-German trade, reaching a share of more than $40 \%$. Nevertheless, it acted within the economic policy decreed by the SED, which was not put into question. ${ }^{18}$

Already in August 1971, the Council of Ministers regarded the balance of payments as a major problem. However, there was no easy way out. The need for further imports clashed with a level of debt that was regarded as unreasonable. The aim of increasing exports to the West clashed with export obligations to the CMEA countries, which secured the necessary supply of raw materials. ${ }^{19}$ Was there a real economic strategy, or did the preservation of power shape policy the most? The consumerist turn in the early Honecker era points in the latter direction and reduced the available funds for innovation and the technology offensive of the late Ulbricht years. However, soon after this policy shift, investments in the East German economy continued to serve foreign trade purposes. Modernisation through imports based on loans was initially regarded a temporary necessity but 


\section{Maximilian Graf}

developed into a permanent strategy. As it turned out, subsequent import substitution did not work. Investments in other sectors were too small and never paid back sufficiently. In a meeting of the State Planning Commission in 1972, Deputy Chairman Heinz Klopfer recalled that the investments were intended to increase exports and stated, 'The opposite is the case. The stream of imports has more and more increased. In my view, this is the main reason for our current situation' ${ }^{20}$ Although the debt was small in comparison with later years, the ratio of liabilities to annual export revenue was already alarming. However, in the age of easy access to cheap money the downside of this economic policy seemed negligible, or at least far away. When criticised for increasing debts in 1972, Honecker remarked that he 'did not intend to pay back the GDR's debts within two years'. ${ }^{21}$

In the first half of the 1970s it seemed that global economic and financial developments might work in favour of socialism. The monetary crisis following the end of the Bretton Woods system, and the first oil shock of 1973 troubled the Western economies. Initially, the crisis was interpreted in classical ideological terms by academics and the party alike. The dictum of the "chronic contradictions of the imperialist system' was in vogue again. ${ }^{22}$ Although to the foreign trade ministry it was clear that economic turbulence would limit the sales markets for exports and worsen conditions for financing imports, ${ }^{23}$ the effects that global economic changes would have on the GDR were hardly predicted and did not lead to policy changes. The oil shock can be seen in this regard. In the long run it resulted in high costs and massively influenced the domestic energy strategy, ${ }^{24}$ but initially and throughout the 1970s the GDR profited from rising world market prices. The export of refinery products made from cheap Soviet crude oil increased and has been interpreted as a logical answer to the need to earn more hard currency. ${ }^{25}$ Indeed, the export of processed oil products to West Berlin was lucrative, and profits increased with the second oil shock in 1979. ${ }^{26}$

However, even before the first shock, it had become clear that there would be no endless raw material supply from the USSR. ${ }^{27}$ In May 1973, chief planner Nikolai Baibakov informed the East Germans that the Soviet Union 'had overextended itself' with promises of deliveries. ${ }^{28}$ With regard to oil and rolled steel, this was a massive blow to the GDR's long-term export planning. East Berlin's acknowledgment that this would further increase imports from the West did not change the Soviet position even though the Kremlin worried about East German indebtedness. In August 1973, Prime Ministers Stoph and Aleksei Kosygin discussed the figures in detail. Annual payment obligations started to exceed the annual export earnings. This was considered the absolute maximum. Nevertheless, Stoph expected debt to rise further and told Kosygin that any forecast up to 1980 depended on the raw materials supplied by the Soviet Union and the other CMEA countries. In a nutshell, the GDR openly admitted that without growing quantities of cheap raw material from the USSR, indebtedness would continue to rise. Only increased production with this support could counteract this development. Kosygin remarked that the socialist countries must capitalise on the economic chaos in the West but conceded that Moscow had no idea how this could be done. ${ }^{29}$ Neither had the GDR. In the age of détente, East German dealings with the West focused on other things: politics dominated over economics. 
After twenty years of international isolation, by the early 1970s diplomatic recognition of the GDR in the West was under way due to the West German Neue Ostpolitik and the Soviet Union pushing through its own détente goals. The conclusion of the Basic Treaty in 1972 was a political bargain in which the GDR had to concede increasing contacts with the FRG and received economic benefits in return. ${ }^{30}$ Serving 'the economic interests of the GDR', as the politburo stated, intra-German trade remained unchanged. ${ }^{31}$ Entirely different assessments existed about its future development. In 1970, the Ministry of Foreign Trade expected a change in global economic developments in favour of the socialist world and anticipated a decreasing dependence on the FRG as a result of growing diversification of trade with the West. ${ }^{32}$ In contrast, in 1973 the State Planning Commission warned that the danger of economic dependency on the FRG was still underestimated. ${ }^{33}$ However, a turnaround was not in sight. The FRG was by far the most important Western trading partner and overall second only to the Soviet Union. While intra-German trade doubled in nominal value during the 1970s, in other fields the GDR aimed at a demarcation from the FRG. East Berlin refused to make any change to the border regime and doubled the minimum exchange rate of DM for West German visitors in 1973. Only economic pressure undermined this strategy. In 1974, after lengthy negotiations, East Berlin accepted some easing of the travel regime in exchange for a prolongation of the "swing". ${ }^{34}$ Concessions to maintain favourable economic ties were unavoidable but no formal linkage was accepted. East Berlin's attitude to the FRG remained ambivalent. It 'oscillated between cooperation and demarcation', and sometime these antipodes could also coexist. ${ }^{35}$ In 1975, cooperation agreements with the West German companies Krupp and Hoechst were concluded (enabling loan-financed imports of steel and chemical plants). ${ }^{36}$ Political dialogue continued, based on the assumption that the division of Germany was permanent, ${ }^{37}$ but even in the heyday of détente, increasing contacts across the border were not on the agenda.

After the Basic Treaty, the EEC member states recognised East Germany and it was admitted to the United Nations. International recognition increased the GDR's prestige, contributed to the legitimacy of its leadership and was another source of optimism. The GDR participated in the CSCE from the very beginning and the SED leaders celebrated the signing of the Final Act as the endpoint of achieving international recognition. Although the ministerial bureaucracy anticipated several potential consequences, in the mid-1970s the regime felt secure and the population seemed more satisfied, not least due to social and consumerist improvements. Dissidence was repressed and Western influence kept out to the best possible extent. However, the rising number of people requesting to permanently leave East Germany had been underestimated, even by the Ministry of State Security. In the long term, this seriously harmed the legitimacy of the SED regime. ${ }^{38}$ On the one hand, demarcation from the West increased. On the other, political and economic relations were about to be further developed. When the economic situation worsened, the GDR's approach to East-West relations came under pressure, but it was formally, though not consistently, upheld throughout the "long 1970s".

Apart from international recognition, the first half of the 1970s brought only limited political success regarding relations with the West. Only a few treaties 


\section{Maximilian Graf}

were signed, and state visits remained scarce. ${ }^{39}$ As always in East-West relations, economics came first. Given that intra-German trade represented the largest share of the GDR's Western trade (more than 30\%, and at times up to $40 \%$ and beyond), ${ }^{40}$ the relevance of other Western states had its limits. Aiming to create a counterbalance to its dependence on the FRG, the GDR tried to exploit the rest of the West. Those who agreed to visibly improve political relations became preferred economic partners. After recognition, some of the European neutral states took the lead. ${ }^{41}$ Among the EEC members, France, Italy and the UK were of most interest, ${ }^{42}$ but the development of economic relations was immediately influenced by the progress of European integration.

In the first two post-war decades, the GDR denounced every form of Western European integration as directed against the socialist camp and consistently argued that the project would fail due to the 'contradictions of imperialism'. From the mid-1960s onwards, a more nuanced approach evolved in the state and party apparatus. ${ }^{43}$ In the late 1960 s, the SED top level had come to terms with the EEC as a reality but refused to recognise it as a political entity. The Community's economic efficiency and political attractiveness were acknowledged internally, ${ }^{44}$ although traditional ideological patterns of capitalism analysis prevailed. In 1972 the politburo did not doubt the further progress of integration, but it expected enlargement in 1973 to cause conflicts among the main 'capitalist powers', which would be exacerbated by 'cyclical crises of capitalism'. ${ }^{45}$

Since the second half of the 1960s, the CMEA's EEC policy had become a major issue in intra-bloc discussions. Facing protectionism, Romania, Hungary, Poland and Bulgaria had hardly any other option than to deal with the Community to maintain the quantity of their exports. Hence, these countries aimed at a more flexible policy, while the Soviet Union and the GDR advocated strict non-recognition of the EEC. ${ }^{46}$ The East German leadership was conscious of the socialist states' need for Western technology, which had to be paid for by exports, but it did not expect any easing from Brussels. Despite the meagre results of the Comprehensive Programme, the GDR demanded deeper integration of the CMEA and a coordinated policy towards the EEC, ${ }^{47}$ a stance that sometimes brought it to the 'brink of isolation' within the socialist camp. ${ }^{48}$

Due to its special situation, the progress of Western integration initially affected the GDR less than other countries. The status quo of intra-German trade remained in place; for the other member states the newly recognised GDR became a third country. ${ }^{49}$ Since the GDR had never stipulated a trade agreement with any of them, the changes resulting from the EEC's Common Commercial Policy (CCP) seemed to be limited. On the contrary, the recently concluded cooperation agreements with almost all the Western countries were regarded as progress. However, none of them was ready to violate the CCP. ${ }^{50}$

Nevertheless, the GDR opted for bilateralism when dealing with the EEC members until it recognised that ignoring the Community had repercussions on trade. When additional charges caused losses to the export of pigs and pork to Italy and France in 1975, the Ministry of Foreign Trade recommended commencing technical contacts. ${ }^{51}$ The GDR gathered detailed information about the EEC modus 
operandi from Hungary. After consultation with the responsible party units, the politburo regretfully concluded that a concerted action by the CMEA was no longer possible and the GDR could only follow the path of the other member states. The SED accepted the advice from the state bureaucracy and approved the establishment of 'technical contacts of companies and institutions of the GDR with the EEC organs'. ${ }^{52}$ While acknowledging that the GDR, like the other socialist states, could solve all economic questions directly with the EEC, in 1977 the Ministry of Foreign Trade stressed the political importance of a desired agreement between CMEA and EEC. ${ }^{53}$ In an internal note, academic Hermann von Berg asked whether a framework agreement with the EC would not be the best solution and questioned if the GDR had a strategy at all. In his view, relations with the EEC were primarily shaped by the FRG's stance within the Community and it was in the GDR's interest that no questions regarding intra-German trade were raised during the CMEA-EEC negotiations. Furthermore, he wondered why the GDR was still so reluctant to conduct technical contacts and accepted the economic disadvantages. ${ }^{54}$

In 1977, the implementation of the EEC's common fisheries policy induced Poland, the USSR and the GDR to open direct negotiations. ${ }^{55}$ Since a substantial economic interest was impaired, the politburo agreed to talk to the Commission but insisted that this would not imply recognition of the EEC. ${ }^{56}$ The negotiations finally failed due to the question of the inclusion of the Berlin clause. Honecker personally authorised every step during the negotiations and interfered in the formulations regarding Berlin. ${ }^{57}$ The Common Market's increasing protectionism made the GDR's economic relations with the West no easier. However, the already inconsistent policy of non-recognition did not change, and bilateralism in relations with the West prevailed.

\section{The fateful years: prestige, dependence and the debt crisis}

In the second half of the 1970s, political relations with the West intensified, yet East German efforts achieved only limited results. From 1975 to 1978, first visits at the foreign minister level took place. Foreign Minister Oskar Fischer travelled to all the EEC capitals except Bonn and Dublin (since Ireland abstained from recognising the GDR until 1980). Several Western foreign ministers paid return visits to East Berlin, but only towards the end of the decade did high-level diplomatic encounters intensify. Visits by the heads of government or state only followed in the 1980s. To the public, all the visits and agreements were sold as proof of the international reputation the GDR had achieved. Regularly dominating the headlines of East German media, they were portrayed as the GDR's contribution to détente and economic cooperation in Europe (after 1975, always with reference to the CSCE). Naturally the public was not informed about the consequences of increasing economic exchanges with the West. ${ }^{58}$

Internally, the dilemma of import needs and growing indebtedness was omnipresent. The establishment of crisis management bodies like the Economic Commission and the Balance of Payments Working Group in 1976, together with the increasing relevance of KoKo, are proof of this. A permanent issue on the agendas 


\section{Maximilian Graf}

of all the economic bodies was reducing imports from the West, but sometimes the only path to reach this goal was further investment in industrial sectors that still demanded imports to fully function. The top-down implementation of import reduction through the plan failed due to the needs and obstinacy of various industrial sectors which had to keep buying from the West. ${ }^{59}$ With debt on the rise, the GDR's ability to meet its financial obligations was endangered. ${ }^{60}$ The outlook for the 1976-80 planning period was bleak, and avoiding bankruptcy seemed to be the real Main Task. ${ }^{61}$

The internal discussions reveal a strange dualism of realism and delusion. In a meeting of the small circle in November 1976, Schürer stated, 'The gap between imports and exports has widened further but it has to be closed by all means. That is a fateful question for the GDR'. Some considered rigorous import cuts; others reasoned about the causes within the CMEA and a re-prioritisation of investments. Stoph argued that major insecurity resulted from the development of the capitalist economy. Mittag endorsed this view by pointing to the difficulties in selling on Western markets. However, he also mentioned examples of favourable trade relations, such as with Greece, where the GDR had a high market share in machinery and imported agricultural products. Additionally, he highlighted the growing Western acceptance of countertrades. Contracts with France and Japan resulted in increasing trade volumes and constituted the best positions in the balance of payments. Mittag wanted to continue along this path. Honecker concluded that the 1976-80 plan was shaped by enforcement of the Unity of Economic and Social Policy. He stated: 'We can only walk our socialist path. The capitalists are currently cutting everything that serves social policy.... We shall not and cannot limit this side'. Whether a delusion or belief, Honecker remarked further:

The GDR is admired by many. Capitalism has taken the path of deflation or inflation. We are not taking those roads. We tread the path of planned and proportional development of our economy on an ever-higher level. . . We have to keep that course. All this must not be achieved at the expense of the worker's bones.

Regarding foreign trade, he said, 'We have to master the new problems due to the pressure external commerce exerts on our republic'. Honecker did not expect any progress in CMEA integration, expressed his worries about the balance of payments, and advocated increasing exports to the West and developing countries as well as cooperation in third markets if they earned hard currency. Like Mittag, he saw potential in trade with the West. He mentioned Greece and Sweden, countertrades with France and Japan, and similar possibilities with Italy and the US that would enable East German production to expand. ${ }^{62}$

In summer 1976, Honecker told Leonid Brezhnev that the GDR possessed a 'special plan to become independent from the West', but he did not detail it. ${ }^{63}$ The archival documents do not reveal any such plan, but it is very likely that modernisation through countertrades resulting in increased exports to the West was his core idea and hope. The most convenient solution would have been to solve the 
hard-currency deficit by making use of the differences between CMEA and world market prices for Soviet raw materials. However, these hopes were shattered by Kosygin in a conversation with Stoph at the end of 1976 when he stated that increased imports of such valuable resources would have to be paid for in hard currency. In March 1977, the balance of payments had worsened to such an extent that Schürer and Mittag for once joined forces and reported to Honecker, 'For the first time, we are in acute financial difficulties'. When confronted with their call to immediately change trade policy, Honecker reacted furiously. He regarded their step as an all-out attack on him and his economic policy. In the end, Mittag and Schürer backed down. ${ }^{64}$ In the next meeting of the small circle, the general secretary proposed to solve the acute problems by making use of existing secret reserves (like West German subsidies, which were under his exclusive control and probably contributed to his rather relaxed attitude). However, he regarded this as a last resort. ${ }^{65}$

In 1977, East Germany's export earnings did not suffice to service its debts. At the end of 1978 the balance of payments showed a deficit of 17.8 billion Valutamark (VM $)^{66}$ in convertible currencies. Ninety percent of the imports from the West were loan-financed. Interest payments and amortisations required new loans. As always, the East German leadership intended to solve this problem by reducing imports, increasing exports and adopting other measures that throughout the 1970s constantly failed to materialise. Nevertheless, not everything was a direct result of the state planning system's failure. Global developments were beyond the SED's control. According to East German estimates, the 1971-78 rise in world market prices had increased the deficit by 3.1 billion VM and unplanned imports of grain (due to crop shortfalls in the GDR and the USSR) added another 3.8 billion VM. The overall outlook was bleak. Since the annual hard-currency spending on interest payments and amortisations exceeded export earnings, the deficit was growing year after year. An analysis of the GDR's balance of payments in 1978 by Schürer, Böhm, Kaminsky and Polze stated the obvious: 'This spiral cannot be prolonged'. It was entirely clear that 'without the willingness of foreign, and especially capitalist, banks to provide further loans of the amount needed, the planned imports and the due payment obligations cannot be realised'. Without a fundamental turnaround in the GDR's trade balance with the West, debt was expected to skyrocket until the mid-1980s. ${ }^{67}$ In November 1980, the economic experts of the Ministry of State Security advocated a complete stop to all imports from the West that were not indispensable to keep production afloat. ${ }^{68}$

Nevertheless, the GDR's assessment of the economic situation in Western Europe seems to have encouraged its economic elite to pursue the path of loanfinanced imports and countertrades further - there seemed to be no alternative ${ }^{69}$ In Italy, GDR foreign traders registered a growing interest in developing economic relations and aimed to treble the trade volume until $1980 .{ }^{70}$ In the case of France, the economic situation of the country was seen as an incentive for more intense economic relations with the GDR..$^{71}$ One of the preferred strategies was loan-financed countertrades - a business model that made the development of exports a bit more plannable and secured at least some revenue. Usually, these 


\section{Maximilian Graf}

deals had a credit period of up to eight years and favourable credit conditions. Additionally, the compensation principle guaranteed certain exports in return (up to $100 \%$, but generally way below $50 \%)^{72}$

Internal plans for loan-financed countertrades reveal how debt-driven this business had become. In 1978, State Secretary Gerhard Beil, who was in charge of day-to-day business in trade relations with the West, prepared a detailed list of the sums available for export funding and loans in various Western countries that would not impair the credit volumes of the East German Foreign Trade Bank. The overall volume amounted to 7.9 billion VM. ${ }^{73}$ In 1979 the GDR planned to conclude countertrades worth more than 15 billion VM. ${ }^{74}$ Despite the year-long failure to reach a balanced trade with the West, Honecker objected to any negative views on compensation within the state and party economic elite: 'This is nonsense. It is of great value for us. We import to export in the future' ${ }^{75}$ In the view of his opponents, the general secretary and Mittag had entered an economically unjustifiable 'technological alliance with capitalism' camouflaged as countertrades to keep their 'consumer socialism' afloat. ${ }^{76}$

Metallurgy products played an important role in many of these countertrades. In this regard, EEC policies on imports made the life of the East German foreign traders more difficult. Against the backdrop of a crisis in the European steel sector, in December 1977 the European Council 'decided that all countries exporting steel to the EEC' had to conclude bilateral agreements so that the EEC 'could impose price discipline'. ${ }^{77}$ Varying from country to country, up to $100 \%$ of the exports seemed endangered. While in 1975 the Ministry of Foreign Trade had promoted technical contacts with the EEC, in 1978 it warned that sectoral agreements on quotas and minimum prices would go beyond technical contacts. ${ }^{78}$ Again, East Berlin hoped for concerted action by the CMEA members. At the next meeting of the CMEA Executive Committee's Standing Commission on Foreign Trade, Foreign Trade Minister Horst Sölle proposed considering if a threat or actual shifting of the CMEA's steel imports from the Common Market to other suppliers could be used as a means of commercial policy. ${ }^{79}$ While East Germany considered counteraction potentially more effective than negotiations with the Commission, most of the other CMEA countries thought differently. ${ }^{80}$

Within four months, Czechoslovakia concluded an agreement with Brussels and was soon followed by Hungary, Romania and Poland. The GDR and the USSR refused to enter negotiations and faced the consequences. Several EEC countries announced restrictions on East German steel exports. The UK imposed an import contingent, reducing planned exports by $15 \% .{ }^{81}$ Furthermore, many of the loanfinanced steel plants and other industrial complexes predominantly had to be refinanced by metallurgy exports. The GDR had to rely on the good will of its partners. By successfully negotiating with Italy, Beil secured refinancing exports and there was hope that similar results could be reached with other countries. ${ }^{82}$

According to the commercial department of the GDR's embassy in Brussels, the 1977 Davignon Plan for Europe's Steel had led to the establishment of permanent 'working contacts' with other CMEA member embassies in the EEC that aimed to 'secure individual economic interests'. Despite intensive cooperation among the diplomats of the CMEA states, for the East Germans 'their knowledge was only of 
limited use'. Even appealing incentives, like Belgian interlocutors stating that the GDR would be in 'a far better position, if it were willing to negotiate with the EEC', did not change the East German stance. ${ }^{83}$ Instead, the GDR faced several antidumping measures. ${ }^{84}$ To 'prevent economic losses', the Ministry of Foreign Trade decided that foreign trade companies should establish short-term technical contacts with the Commission, which they did in five out of ten cases until mid-1980. ${ }^{85}$

Despite the problems in day-to-day business, no initiative to change policy towards the EEC came from the ministries or foreign trade companies. It was the CMEA Working Group of the SED, headed by Horst Tschanter, that became frustrated about the CMEA's inability to negotiate a treaty with the EEC and in 1979 recommended that the GDR also made its own agreements with the Common Market. ${ }^{86}$ Only in 1981 did the commercial department of the embassy in Brussels argue that an engagement with the EEC regarding certain commodity groups would positively influence exports to the Common Market. ${ }^{87}$ In the end, none of these recommendations led to a policy change. Against all odds, bilateralism continued. At the end of the 1970s, the GDR aimed at a breakthrough in political and economic relations with France. Top-level visits were accompanied by the placing of large-scale orders, and cooperation agreements were concluded. However, even though the trade volume increased significantly in the early 1980s, it hardly ever exceeded $10 \%$ of the volume of intra-German trade. ${ }^{88}$ In 1980, Soviet Minister of Foreign Trade Nikolai Patolichev told the East Germans, 'As soon as France breaks out of the EEC bloc regarding cooperation with the Soviet Union, the EEC measures will be more or less without effect' ${ }^{89}$ The East German economic elite perceived it as characteristic of the French attitude to accept proposals violating certain EEC provisions as long as they did not appear in the official text of the treaty subject to review by the Commission. ${ }^{90}$ East Berlin was in line with Moscow and, indeed, the EEC was definitely not a field on which the SED leaders intended to quarrel with the already suspicious Soviets. Even though attempts to diversify trade continued, West Germany remained by far the most important economic partner in the West. In August 1980, Soviet criticism escalated. At a meeting in Crimea, Brezhnev attacked Honecker's economic policy, the GDR's Western orientation and especially its relations with the FRG..$^{91}$ The Soviet leader was furious about the resulting dependence and repercussions on trade with the USSR. According to Schürer, the 'distinctness and harshness' of his criticism was new in form and scale. Mittag and Honecker engaged in appeasing but countered Brezhnev by blaming Moscow for not satisfying the GDR's raw material needs and defending the resulting increased exchanges with the West as unavoidable. ${ }^{92}$

In fact, because of the Soviet stance and for its very own reasons, in the second half of the 1970s political relations with the FRG stagnated, while economic and financial reasons commanded continued cooperation. ${ }^{93}$ Altogether, the annual lump sums for transit and communication and the money earned from trading political prisoners ${ }^{94}$ increased from 600 million DM in 1975 to 1.556 billion DM in $1979 .{ }^{95}$ In return for benefits beyond this already high level, Bonn demanded concessions in other fields. Additionally, the GDR feared a spillover of EEC protectionism to intra-German trade. ${ }^{96}$ Securing economic exchanges on the best plannable basis made long-term agreements on economic cooperation appealing, 
and in early 1979 the idea of such an accord between the two German states surfaced. ${ }^{97}$ Obviously the Soviet-West German agreement of 1978 served as an incentive, and a first draft was agreed with the USSR. ${ }^{98}$ According to West German sources, Honecker was even willing to give up the benefits of intra-German trade. ${ }^{99}$ The East German sources reveal no such intention, and for the FRG only an agreement not affecting the principles of intra-German trade was conceivable. In the end, no agreement was concluded, most probably because of West German considerations regarding the EEC. ${ }^{100}$

In August 1980, Helmut Schmidt cancelled a visit to the GDR on short notice and Honecker was relieved, despite publicly regretting the cancellation. Like the West German chancellor, he feared potential repercussions of the situation in Poland, with Solidarity turning from a strike committee into a political force. In part a result of Soviet criticism and in part due to the Polish crisis, in autumn 1980 the climate in German-German relations worsened. Honecker issued his Gera demands aiming at basic political concessions (i.e. West German recognition of East German citizenship) and increased the minimum exchange rates for Western visitors to the GDR. Bonn regarded this step as a moral breach of the 1974 compromise, and the expiry of the "swing" agreement at the end of 1981 gave it a lever over the economically ailing GDR. During a visit to the GDR in December 1981, Schmidt granted an interim six-month prolongation of the "swing", pointing out that a future agreement would be psychologically linked to the minimum exchange rates. ${ }^{101}$ Nevertheless, East Germany upheld its dogma that negotiations on economic questions must not be linked with other bilateral issues. ${ }^{102}$ In April 1982, Schalck-Golodkowski, who had a prominent role in developing relations with the FRG, warned that a reduction of the "swing" would strengthen those in the leadership who already advocated economic isolation and closed borders. ${ }^{103} \mathrm{~A}$ compromise was reached in June and constituted a relief during the GDR's debt crisis, which had worsened since the turn of the year.

Apart from the uncertainty about the future of the "swing", the year 1981 had dramatically complicated the economic situation. In the summer, the USSR announced a reduction in crude oil deliveries to the GDR by 2 million tons. This was a massive blow, because the refined oil was sold for hard currency on the world market. According to Krolikowski, Honecker reacted with an 'enforced drift westward'. He wanted to keep the GDR stable with a more 'elastic' approach to the West and the FRG. In November, behind closed doors, central banker Kaminsky confirmed Stoph's assessment of the financial situation: 'If I got it right, without a miracle, we will go bankrupt in 1982 ' ${ }^{104}$ Things became much worse, with a Western 'credit boycott' after the imposition of martial law in Poland on 13 December. The GDR's practice of servicing debts by taking out new loans immediately brought it to the verge of bankruptcy. To the discomfort of most of the economic elite, the politburo opted for a going-out-of-business sale during which everything possible was sold. Even though an active trade balance was achieved, the effort was not enough to prevent insolvency. In spring 1982, debt conversion or bankruptcy seemed unavoidable to many of the GDR's experts, but the leadership determinedly opted to stay solvent. All the secret funds were used, and 
expensive trade operations by KoKo created liquidity. ${ }^{105}$ According to a report by the economic division of the Ministry of State Security, Günter Ehrensperger, the head of the SED's department for Planning and Finance, remarked, 'Mittag has to save his face and to postpone insolvency of the GDR as long as possible'. He 'is fighting for his political existence'. Others even held the revealing view that the future existence of the GDR 'depended solely on the West'. ${ }^{106}$

However, unlike other socialist countries, the GDR did not aim at joining the International Monetary Fund or the World Bank. ${ }^{107}$ The economic elite had toyed with several options. A bailout by the Soviets was favoured by many but was unlikely, yet the USSR helped by selling additional quantities of crude oil for world market prices with favourable credit periods. In return, the GDR exported consumer goods purchased in the West. The immediate conversion of Western export loans and clearing units from intra-German trade into hard currency and large-scale oil deals with the Soviet Union - and interestingly, also Austria - finally secured solvency in 1982-83. Indeed, the USSR contributed much to this, but ironically, it was still Western money that saved the GDR from bankruptcy. The Western vendors providing export loans to boost their own economies became the real creditors. Since these trade operations were extremely expensive, the search for new loans continued. In the early stages of the 'credit boycott', the option of a West German loan following the principle of 'freer movement in return for cash' (the so-called Zurich model) was seriously considered by the GDR. However, a loan of up to 5 billion DM would have required substantial concessions in return, which the SED leadership intended to avoid. Until the government change in Bonn in October 1982 (when Schmidt tumbled in a no-confidence vote and Helmut Kohl became chancellor), no loan was provided. ${ }^{108}$ Finally, two loans of 1 billion DM contrived by the Bavarian Prime Minister Franz-Josef Strauß in 1983 and 1984 released the GDR from its acute debt crisis, not least because they re-established the country's creditability in the international financial markets. ${ }^{109}$ However, they did not solve all the problems and, indeed, allowed the leadership to avoid changes in economic policy.

In a meeting of the small circle after the first Strauß loan held in August 1983, Honecker remarked, 'The Milliardenkredit is not here to bridge gaps in the plan. No minister can rely on this. We have to act as if we did not have the money'. He pointed to the necessity of reducing short- and medium-term loans and continuing the policy of reducing imports and increasing exports. Honecker was fully aware that the prolongation of the extreme foreign trade strategy would face opposition in the West: 'Countries like France, Great Britain and Belgium, with whom we have an active balance, also want to sell and not only buy'. However, at that time there was still no alternative to reducing imports and selling oil on the world market. Nevertheless, pointing to developments in the other socialist countries, Honecker stated, 'I want to put on record that our economic system is altogether in best order. It just depends on using the advantages of socialism properly. I am saying this because there is talk about reforms in many countries' ${ }^{110}$ Indeed, despite and because of its own reform experiment in the 1960s, the East German leadership had always been highly sceptical about reform attempts by other socialist states. 
Although the preceding statements leave few doubts that Honecker's dealing with the 'necessary evil' was primarily aimed at securing power by continuing his economic policy, his critics saw it differently and so did Moscow. ${ }^{111}$ In 1984, immediately after the second Strauß loan and with preparations for a visit by Honecker to the FRG in full swing, the East German leadership was called to the Kremlin. The CPSU leaders harshly criticised Honecker's policy towards the FRG and pressed him to cancel his visit. ${ }^{112}$ However, the question remains: were Honecker's opponents right when they denounced him in Moscow, claiming that he did not believe in socialism anymore and only reached out for cooperation with the West and especially with West Germany? Indeed, not least because of economic needs, relations with the FRG intensified and demanded concessions in return, but their development was a visible proof of the existence of an independent GDR under SED rule, which Honecker's politics aimed to make permanent. ${ }^{113}$ However, the economic foundations of the second German state had further weakened and the shortcomings of socialist integration were frustrating. Permanently facing the more functional West changed perceptions of it.

Despite continually deploring EEC protectionism, the East German view of Western European integration had altered profoundly since the mid-1970s. First came academics, followed by officials in the ministries involved (although at different levels), and somehow this knowledge also made it up to the top level of the party. Regarding the EEC, the Institute of International Politics and Economics (IPW) was the most important academic institution. Founded in 1971, it primarily focused on West Germany, but right from the start European integration was also on its research agenda. Because of scientific contacts with the West and analyses based on Western materials, the IPW was something special within the GDR, although at least in the first few years it remained an ideological think tank presenting results according to the official party line. ${ }^{114}$ Over the years, the IPW's analyses improved and the image of the EEC as a growing and more integrated community underwent a change. Despite still playing on the 'irreconcilable antagonisms of capitalism', the EEC member states' ability to compromise in decision-making processes was gradually recognised. ${ }^{115}$

This became visible in 1976 when the IPW analysed the Tindemans Report for the politburo. It was perceived as an attempt to overcome the crisis of Western Europe and the 'so far severest crisis' in its integration. Instead of predicting a foreseeable failure, the analysis acknowledged the will and the ability of the EEC to overcome crises. The conclusion stated:

Altogether, it can be expected that due to the mentioned contradictions the proposals of the 'Tindemans report' will be subject to multiple trade-offs and in most cases only compromises on the least common denominator will materialise. However, in the basic direction, certain enhancements of West European integration will take place. ${ }^{116}$

The Foreign Ministry was a little more cautious in its assessment, considering 'agreements on certain aspects' possible. ${ }^{117}$ However, the prospect of a 'European 
Union' constituted a nightmare, and the foreign policy goal was still to 'make use of all contradictions in order to delay or obstruct integration processes especially in the political and military field'. ${ }^{118}$ The analyses produced in the following years show that the basic assessments on the prospects for integration were stable. Furthermore, the EEC was explicitly recognised as the core of the Western European 'imperialist power centre', which especially economically had gained 'weight, importance and influence in the capitalist world'. Through its internal development, enlargement and the expansion of its economic sphere of influence, the EEC had become a 'considerable competitor of the USA'.119 The approaching second enlargement of the EEC was primarily seen as 'politically motivated' and the candidate countries (Greece, Spain and Portugal) were qualified as 'politically unstable and economically less developed capitalist states', yet the consequences for GDR trade were foreseeable. ${ }^{120}$ Interestingly, despite the decried protectionism of the Common Market and non-recognition of the EEC, the example of Western European integration was increasingly regarded as something to strive for in the CMEA.

Not least, Honecker started to regard the EEC as a desirable model for the CMEA. Against the background of the first elections to the European parliament in 1979, he told CMEA Secretary Nikolai Faddeev that this Western step must be an incentive for closer integration in the East, and one should not allow Romania to obstruct it. ${ }^{121}$ In 1982, Honecker told Soviet Foreign Minister Andrei Gromyko that 'despite the contradictions in the EC', the economic integration of the West 'is further developed than in the CMEA'. ${ }^{122}$ In March 1983, in a conversation with Hungarian politburo member Görgy Aczél, Honecker openly spoke about the differences between the CMEA and the EEC. He pointed to the fact that

despite unemployment, the EC functions better than the CMEA. In principle, the CMEA is based on bilateral relations and does not fulfil the tasks which the EC accomplishes. The EC has a council of ministers, commissions, a parliament, that indeed has not much say, while the socialist world is separated into single states.

Towards the end of his remarks he frustratedly stated that in the CMEA

not even the transport of goods works smoothly. Recently, there was a traffic jam at one of the stations on the Soviet border in which trains with 650 wagons were caught. There was a tailback to the factories. There are no such incidents in the EC. North-south traffic does not run smoothly either. Fruit from Bulgaria is stopped en route at closed frontiers and then arrives in Berlin rotten. ${ }^{123}$

\section{Conclusion}

Certainly, many SED leaders still believed that capitalism was doomed, but by the years of the debt crisis there was a certainty that even the crisis-ridden West functioned better, something that became evident in assessments of the EEC. From 


\section{Maximilian Graf}

a capitalist stillbirth, Western European integration had turned into a role model for the CMEA. Despite this, the GDR still refused to recognise the EEC. East Berlin stuck with Moscow's line and had to face the consequences. Even though access to the Common Market was decisively privileged due to the unique intraGerman trade, in its economic relations with the rest of the West the GDR was no less affected by the progress of European integration than the other socialist states. The CCP also applied to the GDR, and EEC protectionism impaired its economic interests. This became clear already in the first half of the 1970 s, a time when politics dominated over economics in East Berlin's rationale in dealing with the West.

At the beginning of the 1970s, the long-isolated East German regime gained international recognition. The SED leadership celebrated this development and aimed at a diversification of its relations with the West, not least (as ever since) to reduce dependence on the FRG. Their increase had been one of the reasons for the abortion of the economic reforms (which had included an import-financed technology offensive) and the change in the party leadership in 1971. Nevertheless, regarding foreign trade and indebtedness to the West, continuities from the 1960s predominated. Basic economic reasons were the driving factor. As in the case of Czechoslovakia, regardless of political decisions certain components and raw materials had to be bought in the West to keep the comparatively welldeveloped industrial production afloat. Additionally, loan-financed investments seemed to be the only possible way to modernise the economy and to improve its competitiveness. The consumerist turn in the Honecker era reduced the financial leeway in this regard. Growing debt immediately led to internal criticism by economic experts, but it fell on deaf ears and the course was not changed. In the hopeful years, stability mattered more and the downside seemed far away. As in Poland, there was hope that investments would pay back and time would work in the direction of socialism. Throughout the 1970s, cheap Soviet crude oil allowed hard currency to be earned by selling refined products. Additionally, various nontrade-related economic exchanges, or more precisely West German subsidies for the GDR, eased the life of the SED leadership, but it had to make concessions in return. In order to avoid them, other Western countries gained importance. Attempts to diversify Western trade intensified but in the end remained limited to several loan-financed large-scale orders and the respective countertrades. Apart from international recognition, no real breakthrough in relations with the West was achieved during the 1970s, and the development of economic relations was additionally impaired by the progress of European integration. A real counterbalance to dependence on the FRG was out of reach.

Because of costly consumer socialism and continual trade deficits with the West (similar to Poland and Hungary), the East German balance of payments crisis worsened towards the end of the 1970s. Despite all internal warnings and massive Soviet complaints about dependence on the West, the concept of the Unity of Economic and Social Policy remained unchanged, and all the measures taken to reach a favourable trade balance proved insufficient. On the one hand, the much-needed cooperation with the West had caused financial dependence and conflict with the Soviets. On the other hand, the developments in neighbouring Poland once again 
showed that any change in social policy was too risky. ${ }^{124}$ Declining Soviet support (raw materials) and the financial turbulence in other socialist states (Poland, Romania) made the situation even worse. In spring 1982, the GDR faced a Western credit boycott, and bankruptcy seemed unavoidable. By implementing several emergency measures, ironically still financed with Western money, solvency was secured in the short term. In the years of the debt crisis, East Berlin's leeway was more limited than ever. Within the limits Honecker perceived as tolerable for the infinite existence of two German states, he turned to the FRG until Moscow showed the red light. However, this outcome was not the result of a political westward drift aiming at closer bonds with the FRG; it was rooted in the particularity of the GDR and reflected the unresolvable paradoxes in the existence of the second German state. The East German economy had drifted westward ever since and, indeed, since progress in CEMA integration never materialised, only increasing economic cooperation with the West seemed to have the potential to lay the foundations of a stable and independent GDR. Although the result was the opposite, the aims of the economic strategy clearly indicate that in a political sense no westward drift took place. The desired but deceiving financial salvation came in the form of the Strauß loans in 1983-84. Regardless of potential Western intentions behind them, it was their unintended consequences that contributed to the demise of the GDR, namely allowing the leadership to proceed with its failed economic policy. ${ }^{125}$ The SED rule survived a severe economic crisis and secured the existence of a socialist Germany in the short term. However, surviving the debt crisis in 1982-83 proved to be a Pyrrhic victory. The measures taken caused growing dependence on the FRG, continuing economic decline and lowered East German living standards. Against the background of a changed international environment, these factors decisively contributed to the collapse of the GDR in $1989 . .^{126}$

\section{Notes}

1 Note by Werner Krolikowski on the internal situation of the GDR, 30 March 1983, in Przybylski, Tatort Politbüro, 349-56, 351.

2 Malycha, Die SED in der Ära Honecker, 243-56. On the internal conflicts about Germany policy, see Amos, SED-Deutschlandpolitik, 347-62.

3 Selvage and Süß, Staatssicherheit und KSZE-Prozess, 222-31, 397-421.

4 Malycha, Die SED in der Ära Honecker, 177-322; Steiner, The plans that failed; Steiner, Überholen ohne einzuholen; Berghoff and Balbier, The East German Economy, 1945-2010; Hoffmann, Die zentrale Wirtschaftsverwaltung in der SBZ/DDR; Zatlin, The currency of socialism; Ahrens, Gegenseitige Wirtschaftshilfe?; Hertle, "Die Diskussion der ökonomischen Krisen," 309-45.

5 For the best accounts, see Wentker, Außenpolitik in engen Grenzen; Siebs, Die Außenpolitik der DDR 1976-1989.

6 Especially the neutrals Austria and Finland as well as Japan played an important role exceeding that played by smaller EEC states. Maximilian Graf, Österreich und die DDR.

7 For the most recent studies on bilateral relations regarding the countries under discussion and addressing the 1970s, see Wenkel, Auf der Suche nach einem "anderen Deutschland"; Pfeil, Die "anderen" deutsch-französischen Beziehungen; Fasanaro, La DDR e l'Italia; Berger and LaPorte, Friendly enemies; Pekelder, Die Niederlande und die DDR; Pfeil, Die DDR und der Westen. 
8 Wüstenhagen, "Blick durch den Vorhang”; Schmidt, Europäische Gemeinschaft; Müller, "Ex oriente luxus?," 187-212.

9 Fäßler, Durch den "Eisernen Vorhang"; Kruse, Politik und deutsch-deutsche Wirtschaftsbeziehungen.

10 Through intra-German trade the GDR had some sort of 'freeway' into the Common Market, but the FRG had to inform the EEC about the imports. According to Bonn, less than $1 \%$ of the volume of intra-German trade was re-exported into the Common Market, amounting to only $0.02 \%$ of overall West German exports. Thus, in comparison to the economic benefits resulting from intra-German trade, the additional benefits of exporting via West Germany were negligible. Nakath, "Die DDR - "heimliches Mitglied'," 451-73. For a detailed discussion of this issue, see Graf, "Die DDR und die EWG 1957-1990," 21-35; Graf, "Nichtanerkennung zu eigenen Lasten?," 225-38.

11 Wenkel, Auf der Suche nach einem "anderen Deutschland," 148-61; Pfeil, Die "anderen" deutsch-französischen Beziehungen, 393-413. Bundesarchiv, Abteilung DDR (BArch-DDR), DL 2/6235, Information über Verlängerung der Kreditlaufzeiten von 5 auf 8 Jahre beim Import aus EWG-Ländern, Berlin, 14 August 1970.

12 Ahrens, "Außenwirtschaft zwischen Ostintegration und Westverschuldung," 510-90, for the figures see 561; and Ahrens, "Debt, cooperation, and collapse," 161-76, for the quote see 176 .

13 Steiner, Die DDR-Wirtschaftsreform der sechziger Jahre.

14 For details, see Steiner, The plans that failed, 141-69; Hertle, "Die Diskussion der ökonomischen Krisen," 311-19; Ahrens, Gegenseitige Wirtschaftshilfe?, 268-9; Malycha, Die SED in der Ära Honecker, 186-95.

15 According to a recent biography, distrust of his own people was one of the most determining imprints on Honecker, who had witnessed the people's support for the Nazi regime. Sabrow, Erich Honecker, 504-5.

16 Ahrens, Gegenseitige Wirtschaftshilfe?, 250-1.

17 Schürer, Gewagt und verloren, 114-17.

18 Judt, Der Bereich Kommerzielle Koordinierung.

19 BArch-DDR, DE 1/58539, B1. 88-100, Memorandum on the discussion of the plan 1971-75 in the Council of Ministers, 21 July 1971.

20 BArch-DDR, DE 1/58539, B1. 233-247, Memorandum on a meeting by the Deputy Heads of the State Planning Commission, 15 February 1972.

21 Already in 1970, the total debts of the GDR in the West had amounted to $50 \%$ of the annual East German exports to the West. Ahrens, Gegenseitige Wirtschaftshilfe?, 235-6, 239, for the quote 269.

22 Stiftung Archiv der Parteien und Massenorganisationen der ehemaligen DDR im Bundesarchiv (SAPMO-BArch), DY 30/J IV 2/2J/4555, "Information über die aktuelle Lage der Entwicklung der kapitalistischen Währungskrise für das SED-Politbüro" (information for the politburo on the current situation and development of the capitalist monetary crisis), 12 February 1973; SAPMO-BArch, DY 30/J IV 2/2J/5319, "Information für das SED-Politbüro. Zur gegenwärtigen Lage der Wirtschaft in den kapitalistischen Hauptländern" (information for the politburo on the current situation of the economy in the main capitalist countries), May 1974.

23 SAPMO-BArch, DY 30/17790, "Information Nr. 9/I" (information on the economic development of France 1973/74).

24 On rising oil prices and the repercussions, see Steiner, "Common sense is necessary'," 231-50.

25 Stokes, "From schadenfreude to going-out-of-business sale," 131-43, 142.

26 Judt, Der Bereich Kommerzielle Koordinierung, 62-6, 105-12, 183-4.

27 Ahrens, Gegenseitige Wirtschaftshilfe?, 275-6. On the origins of this tendency, see Hoffmann and Malycha, Erdöl, Mais und Devisen.

28 BArch-DDR, DE 1/58507, Memcon Schürer - Baibakov, Moscow, 21 May 1973.

29 BArch-DDR, DE 1/58507, Memcon Stoph - Kosygin, Moscow, 20 August 1973. 
30 Sarotte, Dealing with the devil.

31 SAPMO-BArch, DY 30/J IV 2/2/1420, Bl. 6-10, Directive approved by the politburo on 31 October 1972.

32 BArch-DDR, DL 2/6283a, "Erste prognostische Einschätzung der Entwicklung der Außenwirtschaftsbeziehungen der DDR mit der BRD und der selbständigen politischen Einheit Westberlin bis zum Jahre 1990" (first projection of the development of the GDR's economic relations with the FRG and West Berlin until 1990), Berlin, 28 August 1970.

33 BArch-DDR, DE 1/58719, Bl. 212-227, Assessment of the status of the GDR's economic relations with the FRG and West Berlin, 12 January 1973.

34 On German-German relations and the "swing" negotiations, see Dokumente zur Deutschlandpolitik, series VI: 21. Oktober 1969 bis 1. Oktober 1982, vol. 3: 1. Januar 1973 bis 31. Dezember 1974 (DzD VI/3). Munich: Oldenbourg, 2005.

35 Wentker, Außenpolitik in engen Grenzen, 410-11.

36 BArch-DDR, DL 226/1319, B1. 186-194, Information on questions regarding economic relations between the GDR and the FRG, Berlin, 2 December 1975.

37 Amos, SED-Deutschlandpolitik, 273-329.

38 Hanisch, Die DDR im KSZE-Prozess 1972-1985; Selvage and Süß, Staatssicherheit und KSZE-Prozess.

39 Wentker, Außenpolitik in engen Grenzen, 449-59.

40 Due to the limited validity of East German statistics (resulting among other things from the permanent undervaluation of the DM in relation to the GDR mark), no exact figures exist. These are the 'least bad figures'. Ahrens, "Außenwirtschaft zwischen Ostintegration und Westverschuldung," 568.

41 On the example of Austria but with an eye on the other neutrals, see Graf, Österreich und die $D D R$.

42 SAPMO-BArch, DY 30/J IV 2/2A/1849, B1. 55-125, Conception or the development of the GDR's relations with France, Great Britain and Italy until 1977-78, approved by the politburo on 14 January 1975.

43 Wüstenhagen, "Blick durch den Vorhang," 107-41; Schmidt, Europäische Gemeinschaft, 101-47.

44 Müller, "Ex oriente luxus?," 201.

45 SAPMO-BArch, DY 30/J IV 2/2A/1578, B1. 4, 113-122 and 1579, Bl. 1-29, Brief assessment of the EEC, approved by the politburo on 29 February 1972.

46 Kansikas, Socialist countries face the European Community.

47 SAPMO-BArch, DY 30/J IV 2/2A/1601, Bl. 1-36, Meeting of the politburo, 6 June 1972.

48 Wüstenhagen, "RGW und EWG," 135-49, 139.

49 BArch-DDR, DL 2/6290, "Information Nr. 19/4" (information on the EEC's trade policy toward the GDR), Berlin, 31 May 1973; BArch-DDR, DL 2/6287, "Information Nr. 19/ VII" (information on the EEC Commisson's efforts to enforce treatment of the GDR as a 'third country'), Berlin, 23 July 1974. See Chapter 2 by Angela Romano in this book.

50 SAPMO-BArch, DY 30/J IV 2/2A/1845, Bl. 8, 54-67, Meeting of the politburo, 17 December 1974.

51 BArch-DDR, DL 2/11774, "Die Notwendigkeit von technischen Kontakten von Betrieben und Institutionen der DDR zu EWG-Organen zur Sicherung des Exports der DDR sowie Abwendung von ökonomischen Verlusten" (memorandum on the necessity of technical contacts of companies and institutions of the GDR with EEC organs to secure the GDR's exports and to prevent economic losses), Berlin, 25 February 1975; Wüstenhagen, "Blick durch den Vorhang," 284-5.

52 SAPMO-BArch, DY 30/J IV 2/2A/1864, Bl. 65-75, Meeting of the politburo, 7 March 1975.

53 BArch-DDR, DL 2/16751, "Standpunkt der DDR zur Weiterführung der Verhandlungen des RGW mit der EWG" (GDR standpoint on the continuation of negotiations between CMEA and EEC). 
54 BArch-DDR, DL 2/16751, "Bemerkungen zu den vorliegenden Ausarbeitungen RGW-EWG" (remarks on the present papers CMEA-EEC), signed H.v.B. Berlin, 23 February 1977. Von Berg was an academic with a history as secret negotiator who later became a persona non grata because of leaking criticism on the GDR's economic situation to the West German magazine Der Spiegel. See Malycha, Die SED in der Ära Honecker, 219.

55 Angela Romano, "Untying Cold War Knots," 169-70.

56 SAPMO-BArch, DY 30/J IV 2/2A/2047, Bl. 138-146, Meeting of the politburo, 1 March 1977.

57 For the drafts and reports on the negotiations, see Politisches Archiv des Auswärtigen Amts, Ministerium für Auswärtige Angelegenheiten der DDR (PA/AA-MfAA), M 1 C 7135, B1. 1-191; and BArch-DDR, DC 20/4320, Bl. 1-35.

58 This assumption is based on a review of the SED's daily Neues Deutschland and other print media.

59 The Economic Commission was not a decision-making body, but it served as Mittag's tool for the top-down management of the economy. For the Commission's protocols 1976-83, see SAPMO-BArch, DY 30/70615-70676. On the institutional context, see Malycha, Die SED in der Ära Honecker, 92-3, 99-103, 190-1.

60 BArch-DDR, DE 1/58633, Schürer to Honecker, "Information über Grundfragen der Planzahlungsbilanz 1976 mit dem nichtsozialistischen Wirtschaftsgebiet" (information on basic questions of the planned balance of payments with the non-socialist economic area 1976), Berlin, 24 November 1975.

61 BArch-DDR, DE 1/58633, Schürer to Honecker, "Zusammengefaßte Einschätzung zum Entwurf des Fünfjahrplanes 1976-1980" (summarised assessment of the draft of the five-year plan), Berlin, 6 October 1976.

62 BArch-DDR, DE 1/58633, "Niederschrift über eine Beratung zum Entwurf des Fünfjahrplanes 1976-1980 unter Leitung des Generalsekretärs des ZK der SED Genossen Erich Honecker" (memorandum on the discussion of the draft of the five-year plan 1976-1980 presided by Honecker), 5 November 1976.

63 Memcon Honecker - Brezhnev, Berlin, 20 August 1976, in Hertle and Jarausch, Risse im Bruderbund, 113-35, 130.

64 Hertle, "Die Diskussion der ökonomischen Krisen," 314-15.

65 BArch-DDR, DE 1/58719, B1. 482-514, Memorandum on a meeting discussing the 1977 and 1978 plans at Honecker's office, 2 June 1977.

66 In this chapter I use the figures on which internal assessments and decisions were based. On the problem of the actual value of the 'divided' VM and the amount of debt, see Volze, "Zur Devisenverschuldung der DDR," 151-83.

67 BArch-DDR, DL 226/1248, B1. 220-238, Current status of the GDR's balance of payments with the West in 1978/79, Berlin, 1 February 1979.

68 Archiv des Bundesbeauftragten für die Unterlagen des Staatssicherheitsdienstes der ehemaligen DDR (BStU), MfS, HA XVIII, Nr. 4692, B1. 13-38, Recommendations and proposals for solutions in the interest of a further stable growth of the output of the GDR's national economy, 24 November 1980.

69 SAPMO-BArch, DY 3023/1271, Bl. 129-133, Information on Beil's meetings with representatives of the French government and economy in Paris, Berlin, 25 November 1976.

70 SAPMO-BArch, DY 30/17796, "Information über die 4. Tagung der Gemischten Regierungskommission DDR-Italien" (information on the fourth meeting of the mixed governmental commission GDR-Italy), Berlin, 20 May 1977. Fasanaro, $L a$ DDR e l'Italia, $135-54$.

71 SAPMO-BArch, DY 30/17791, "Information über den Aufenthalt einer Staatsdelegation der DDR unter Leitung des Mitgliedes des Politbüros und Sekretär des Zentralkomitees der SED, Genosse Günter Mittag, in Frankreich" (information on the visit by Mittag in France), 5-8 June 1978. 
72 Judt, "Kompensationsgeschäfte der DDR," 117-38.

73 SAPMO-BArch, DY 3023/1302, B1. 299-300, Memorandum on available funds for compensation projects, Berlin, 25 April 1978.

74 SAPMO-BArch, DY 3023/1304, Bl. 180, Information by Beil, Berlin, 13 June 1979; SAPMO-BArch, DY 30/J IV 2/2/1781-1783, Meeting of the politburo, 12 June 1979.

75 BArch-DDR, DE 1/58719, B1. 409-433, Memorandum of the joint meeting of the politburo and the Council of Ministers on the draft plan 1980, Berlin, 4 December 1979.

76 SAPMO-BArch, DY 30/25758, Bl. 19-27, Memorandum by Krolikowski, 24 October 1980.

77 Romano, "Untying Cold War Knots," 167.

78 SAPMO-BArch, DY 3023/1276, B1. 77-80, Information on the impact of the EEC measures in the metallurgy field for the GDR, Berlin, 5 January 1978.

79 SAPMO-BArch, DY 3023/1276, B1. 199-203, Information on a meeting of the ministers during the fifty-first session of the Standing Commission on Foreign Trade, Berlin, 4 April 1978.

80 BArch-DDR, DL 2/20070, "Bericht über die Tagung der Leiter der handelspolitischen Verwaltungen der Ministerien für Außenhandel der ML/RGW" (report on the meeting of the heads of the commercial administrations of the CMEA members' Ministries of Foreign Trade), Warsaw, 18-20 April 1978.

81 SAPMO-BArch, DY 3023/1277, B1. 249-250, Tautenhahn to Mittag, 21 September 1979.

82 Beil managed to secure the import contingents needed for the refinancing of compensation deals with Italy, not least because the Italian Foreign Trade Minister Rinaldo Ossola was lobbying for another big steel plant order by the GDR. SAPMO-BArch, DY 3023/1279, B1. 58-59, Beil to Mittag, Berlin, 1 March 1979; SAPMO-BArch, DY 3023/1279, B1. 113-115, Memcon Mittag - Ossola, Leipzig, 12 March 1979; SAPMO-BArch, DY 3023/1281, Bl. 144-148, Information on the visit by Beil to Italy, 1-3 October 1979.

83 SAPMO-BArch, DY 3023/1281, B1. 278-279, Relations CMEA members - EEC, Brussels, 5 December 1979.

84 SAPMO-BArch, DY 3023/1287, B1. 40, Information on additional anti-dumping procedures by the EEC, 13 September 1982; BArch-DDR, DL 2/6380, Bl. 296-298, Information on anti-dumping procedures against GDR foreign trade companies, 16 September 1981.

85 BArch-DDR, DL 2/16754, "Einschätzung des Standes der Schaffung handelspolitischer Voraussetzungen für die Erfüllung des Planes 1979 gegenüber KIL, BRD/WB und ausgewählten EL" (assessment on anti-dumping procedures and consequences for the export plan), 5 January 1979; BArch-DDR, DL 2/6365a, "Information Nr. 178/1980" (assessment on anti-dumping procedures), 27 June 1980.

86 SAPMO-BArch, DY 30/IV 2/2.036/71, B1. 93-94, Tschanter to Verner, 30 January 1979.

87 BArch-DDR, DL 2/16749, "Einschätzung der Selbstbeschränkungsabkommen und -vereinbarungen im Rahmen der protektionistischen Politik der KIL, insbesondere der EWG" (memorandum), Brussels, 5 March 1981.

88 Wenkel, Auf der Suche nach einem "anderen Deutschland", 173-5; Pfeil, Die "anderen" deutsch-französischen Beziehungen, 451-3, 571-9.

89 SAPMO-BArch, DY 3023/1282, Bl. 20-32, Memcon Krolikowski - Patolichev, 21 January 1980.

90 SAPMO-BArch, DY 3023/1554, B1. 191-196, Information on the conclusion of the agreement on economic, industrial and technical relations between the GDR and France 1980-1985, Berlin, 12 February 1980.

91 Hertle and Jarausch, Risse im Bruderbund, 188-97.

92 BStU, MfS HA XVIII Nr. 26078, B1. 162-164, Information, Berlin, 23 August 1980. 
93 Wentker, Außenpolitik in engen Grenzen, 420; BArch-DDR, DL 226/1319, B1. 255275, Conception for relations to the FRG and West Berlin in 1976, Berlin, 6 February 1975.

94 Wölbern, Der Häftlingsfreikauf aus der DDR 1962/63-1989.

95 Hertle, "Die Diskussion der ökonomischen Krisen," 319 (footnote 36).

96 SAPMO-BArch, DY 3023/1347, Bl. 284-286, Memcon Behrendt - Rohwedder, 17 January 1978; SAPMO-BArch, DY 3023/1347, B1. 292-299, Memcon Sölle Rohwedder, 14 March 1978.

97 BArch-DDR, DL 226/1319, B1. 79-109, Memcon Mittag - Lambsdorff, 23 February 1979; BArch-DDR, DL 226/1319, B1. 44-52, Memcon Sölle - Lambsdorff, 12 March 1979; SAPMO-BArch, DY 3023/1347, B1. 82-93, Memcon Mittag - Lambsdorff, 13 March 1979; also see Akten zur Auswärtigen Politik Deutschlands (AAPD) 1979, vol. 1, 367-72.

98 See the documentation in SAPMO-BArch, DY 30/IV 2/2.035/85, B1. 123-35.

99 Memcon Gaus - Honecker, East Berlin, 12 October 1979, in AAPD 1979, vol. 2, 1441-51.

100 Already in April 1980, the FRG voiced doubts that a long-term agreement would be compatible with the EEC's acceptance of intra-German trade. SAPMO-BArch, DY 3023/1345, B1. 99-100, Memorandum for Beil on the preparation for the visit by Schmidt, Berlin, 20 August 1980.

101 Wentker, Außenpolitik in engen Grenzen, 421-7; DzD VI/7, 423-522; AAPD 1981, vol. 2, 1935-63.

102 SAPMO-BArch, DY 3023/1359, B1. 198-204, Schalck to Mittag, Berlin, 10 April 1980.

103 Report by Bölling on a conversation with Schalck, Berlin, 14 April 1982, in $D z D$ VI/7. 685-8, 686.

104 SAPMO-BArch DY 30/25759, B1. 47-62, Memorandum by Krolikowski, 3 December 1981.

105 For details on the debt crisis, see Graf, "Before Strauß"; Judt, Der Bereich Kommerzielle Koordinierung, 142-74.

106 BStU, MfS HA XVIII 26566, B1. 257-263, Information, 20 May 1982.

107 For details on this issue in a comparative perspective, see Steiner, "The globalisation process and the Eastern Bloc," 172-6.

108 Graf, "Before Strauß."

109 Kieninger, "Freer movement in return for cash," 117-37.

110 BArch-DDR, DE 1/58704, B1. 272-277, Memorandum by Klopfer on the politburo consultations, Berlin, 9 August 1983.

111 SAPMO-BArch DY 30/25759, B1. 129-144, Memorandum by Krolikowski, 16 May 1984.

112 Memcon Honecker - Chernenko, Moscow, 14 June 1984, in DzD VII/1 670-80.

113 Amos, SED-Deutschlandpolitik, 612-13.

114 Klein, Das Institut für Internationale Politik und Wirtschaft.

115 Schwarz, "Das Verhältnis der DDR zur westeuropäischen Integration," 140-57; Schmidt, Europäische Gemeinschaft, 309-403.

116 SAPMO-BArch, DY 30/J IV 2/2J/7124, "Information für das SED-Politbüro. Zum'Tindemans-Bericht' über die Entwicklung der 'Europäischen Gemeinschaft' zur 'Europäischen Union'" (information for the politburo on the 'Tindemans report'), February 1976.

117 PA/AA-MfAA, M 1 C 3525, B1. 7-11, Memorandum by the policy planning department of the foreign ministry on the 'Tindemans report' about the 'European Union'.

118 PA/AA-MfAA, M 1 C 3525, Bl. 22-35, Draft: Assessment on the prospect of the creation of a 'European Union' in Western Europe and conclusions.

119 PA/AA-MfAA, M 1 C 1002/78, Bl. 1-27, Development trends of the 'European Communities,' 1977. 
120 BArch-DDR, DL 2/16735, “Thesen und Probleme zur Erweiterung der 'Europäischen Gemeinschaften' durch Griechenland, Portugal und Spanien" (theses on the enlargement of the 'European Communities' through Greece, Portugal and Spain), 23 January 1979.

121 SAPMO-BArch, DY 30/IV 2/2.036/71, B1. 199-204, Memcon Honecker - Faddeev, 19 March 1979.

122 SAPMO-BArch, DY 30/J IV 2/2A/2457, Bl. 1-21, Report on Gromyko's visit to the GDR, 27/28 January 1982.

123 SAPMO-BArch, DY 30/J IV 2/2A/2551, B1. 192-212, Memcon Honecker - Aczél, 10 March 1983.

124 On the example of state price policy, see Steiner, "State price policy in the German Democratic Republic," 169-89.

125 Zatlin, The currency of socialism, 125-48.

126 The further consequences of the East German effort to avoid bankruptcy for the economic demise of the GDR have been assessed in a similar way by Steiner in The plans that failed.

\section{Bibliography}

\section{Published primary sources}

Akten zur Auswärtigen Politik Deutschlands (AAPD), 1979 and 1981.

Dokumente zur Deutschlandpolitik (DzD), series VI, vols. 3, 7 and series VII, vol. 1.

Hertle, Hans-Hermann and Konrad H. Jarausch, eds. Risse im Bruderbund. Die Gespräche Honecker-Breshnew 1974 bis 1982. Berlin: Ch. Links, 2006.

Hoffmann, Dierk and Andreas Malycha, eds. Erdöl, Mais und Devisen. Die ostdeutschsowjetischen Wirtschaftsbeziehungen 1951-1967. Eine Dokumentation. Berlin: De Gruyter, 2016.

\section{Secondary sources}

Ahrens, Ralf. Gegenseitige Wirtschaftshilfe? Die DDR im RGW. Strukturen und handelspolitische Strategien 1963-1976. Cologne: Böhlau, 2000.

Ahrens, Ralf. "Debt, cooperation, and collapse. East German foreign trade in the Honecker years." In The East German Economy, 1945-2010. Falling behind or catching up?, edited by Hartmut Berghoff and Uta Andrea Balbier, 161-76. New York: Cambridge University Press, 2013.

Ahrens, Ralf. "Außenwirtschaft zwischen Ostintegration und Westverschuldung." In Die zentrale Wirtschaftsverwaltung in der SBZ/DDR. Akteure, Strukturen, Verwaltungspraxis, edited by Dierk Hoffmann, 510-90. Berlin: De Gruyter, 2016.

Amos, Heike. Die SED-Deutschlandpolitik 1961-1989. Ziele, Aktivitäten und Konflikte. Göttingen: Vandenhoeck \& Ruprecht, 2016.

Berger, Stefan and Norman LaPorte. Friendly enemies: Britain and the GDR, 1949-1990. Oxford: Berghahn, 2010.

Berghoff, Hartmut and Uta Andrea Balbier, eds. The East German economy, 1945-2010: falling behind or catching up? New York: Cambridge University Press, 2013.

Fäßler, Peter E. Durch den "Eisernen Vorhang". Die deutsch-deutschen Wirtschaftsbeziehungen 1949-1969. Köln: Böhlau, 2006.

Fasanaro, Laura. La DDR e l'Italia. Politica, commercio e ideologia nell'Europa del cambiamento (1973-1985). Rome: Carocci, 2016. 


\section{Maximilian Graf}

Graf, Maximilian. Österreich und die DDR 1949-1990. Politik und Wirtschaft im Schatten der deutschen Teilung. Vienna: Verlag der Österreichischen Akademie der Wissenschaften, 2016.

Graf, Maximilian. "Before Strauß: the East German struggle to avoid bankruptcy during the debt crisis revisited." The International History Review (2019): 1-18. Accessed 31 March 2020. https://doi.org/10.1080/07075332.2019.1641542.

Graf, Maximilian. "Die DDR und die EWG 1957-1990." Revue d'Allemagne et des pays de langue allemande 51:1 (2019): 21-35.

Graf, Maximilian. "Nichtanerkennung zu eigenen Lasten? Die DDR und die Europäische Wirtschaftsgemeinschaft in den 'langen 1970er-Jahren'." Jahrbuch für historische Kommunismusforschung (2020): 225-38.

Hanisch, Anja. Die DDR im KSZE-Prozess 1972-1985. Zwischen Ostabhängigkeit, Westabgrenzung und Ausreisebewegung. Munich: Oldenbourg, 2012.

Hertle, Hans-Hermann. "Die Diskussion der ökonomischen Krisen in der Führungsspitze der SED." In Der Plan als Befehl und Fiktion. Wirtschaftsführung in der DDR. Gespräche und Analysen, edited by Theo Pirker, M. Rainer Lepsius, Rainer Weinert and Hans-Hermann Hertle, 309-45. Opladen: Westdeutscher Verlag, 1995.

Hoffmann, Dierk, ed. Die zentrale Wirtschaftsverwaltung in der SBZ/DDR. Akteure, Strukturen, Verwaltungspraxis. Berlin: De Gruyter, 2016.

Judt, Matthias. "Kompensationsgeschäfte der DDR - Instrumente einer europäischen OstWest-Wirtschaftsintegration?” Jahrbuch für Wirtschaftsgeschichte 49:2 (2008): 117-38.

Judt, Matthias. Der Bereich Kommerzielle Koordinierung. Das DDR-Wirtschaftsimperium des Alexander Schalck-Golodkowski - Mythos und Realität. Berlin: Ch. Links, 2013.

Kansikas, Suvi. Socialist countries face the European Community: Soviet-bloc controversies over East-West trade. Brussels: Peter Lang, 2014.

Kieninger, Stephan. "Freer movement in return for cash. Franz Josef Strauß, Alexander Schalck-Golodkowski, and the Milliardenkredit for the GDR, 1983-1984." In New perspectives on the end of the Cold War: unexpected transformations?, edited by Bernhard Blumenau, Jussi M. Hanhimäki and Barbara Zanchetta, 117-37. London: Routledge, 2018.

Klein, Michael B. Das Institut für Internationale Politik und Wirtschaft der DDR in seiner Gründungsphase 1971 bis 1974. Berlin: Duncker\&Humblot, 1999.

Kruse, Michael. Politik und deutsch-deutsche Wirtschaftsbeziehungen von 1945 bis 1989. Berlin: Köster, 2005.

Malycha, Andreas. Die SED in der Ära Honecker, Machtstrukturen, Entscheidungsmechanismen und Konfliktfelder in der Staatspartei 1971-1989. Munich: Oldenbourg, 2014.

Müller, Werner. "Ex oriente luxus? - Supranationale Verflechtung der DDR in der Sicht des SED-Politbüros." Jahrbuch für historische Kommunismusforschung (2000/2001): 187-212.

Nakath, Detlef. "Die DDR - 'heimliches Mitglied' der Europäischen Gemeinschaft? Zur Entwicklung des innerdeutschen Handels vor dem Hintergrund der westeuropäischen Integration." In Aufbruch zum Europa der zweiten Generation. Die europäische Einigung 1969-1984, edited by Franz Knipping and Matthias Schönwald, 451-73. Trier: Wissenschaftlicher Verlag, 2004.

Pekelder, Jacco. Die Niederlande und die DDR. Bildformung und Beziehungen 1949-1989. Munster: Agenda, 2002.

Pfeil, Ulrich, ed. Die DDR und der Westen. Transnationale Beziehungen 1949-1989. Berlin: Ch. Links, 2001.

Pfeil, Ulrich. Die “anderen” deutsch-französischen Beziehungen. Die DDR und Frankreich 1949-1990. Cologne: Böhlau, 2004.

Przybylski, Peter. Tatort Politbüro. Die Akte Honecker. Berlin: Rowohlt, 1991. 
Sabrow, Martin. Erich Honecker. Das Leben davor 1912-1945. Munich: C.H. Beck, 2016. Sarotte, Mary E. Dealing with the devil: East Germany, détente, and Ostpolitik, 19691973. Chapel Hill: University of North Carolina Press, 2001.

Schmidt, Klaus-Peter. Die Europäische Gemeinschaft aus Sicht der DDR (1957-1989). Hamburg: Kovač, 1995.

Schürer, Gerhard. Gewagt und verloren. Eine deutsche Biografie. Berlin: Frankfurt Oder Editionen, 1998.

Schwarz, Siegfried. "Das Verhältnis der DDR zur westeuropäischen Integration. Phasen der Wahrnehmung - Umdenken - Annäherung an die Realität (1950-1990)." In Die DDR in Deutschland. Ein Rückblick auf 50 Jahre, edited by Heiner Timmermann, 14057. Berlin: Duncker \& Humblot, 2001.

Selvage, Douglas and Walter Süß. Staatssicherheit und KSZE-Prozess. MfS zwischen SED und KGB (1972-1989). Göttingen: Vandenhoeck \& Ruprecht, 2019.

Siebs, Benno-Eide. Die Außenpolitik der DDR 1976-1989. Strategien und Grenzen. Paderborn: Schöningh, 1999.

Steiner, André. Die DDR-Wirtschaftsreform der sechziger Jahre. Konflikt zwischen Effizienzund Machtkalkül. Berlin: Akademie Verlag, 1999.

Steiner, André, ed. Überholen ohne einzuholen. Die DDR-Wirtschaft als Fußnote der deutschen Geschichte? Berlin: Ch. Links, 2006.

Steiner, André. The plans that failed: An economic history of the GDR. New York: Berghahn, 2010.

Steiner, André. “'Common sense is necessary:' East German reactions to the oil crises of the 1970s." Historical Social Research 39:4 (2014): 231-50.

Steiner, André. "The globalisation process and the Eastern Bloc countries in the 1970s and 1980s." European Review of History 21:2 (2014): 165-81.

Steiner, André. "State price policy in the German Democratic Republic in the 1970s and 1980s." In Calmer les prix. L'inflation en Europe dans les années 1970, edited by MichelPierre Chélini and Laurent Warlouzet, 169-89. Paris: Presse de Sciences Po, 2016.

Stokes, Ray. "From schadenfreude to going-out-of-business sale: East Germany and the oil crises of the 1970s." In The East German economy, 1945-2010: falling behind or catching up?, edited by Hartmut Berghoff and Uta Andrea Balbier, 131-43. New York: Cambridge University Press, 2013.

Volze, Armin. "Zur Devisenverschuldung der DDR - Entstehung, Bewältigung und Folgen." In Die Endzeit der DDR-Wirtschaft - Analysen zur Wirtschafts-, Sozial- und Umweltpolitik, edited by Eberhard Kuhrt, 151-83. Opladen: Leske + Budrich, 1999.

Wenkel, Christian. Auf der Suche nach einem "anderen Deutschland." Das Verhältnis Frankreichs zur DDR im Spannungsfeld von Perzeption und Diplomatie. Munich: Oldenbourg, 2014.

Wentker, Hermann. Außenpolitik in engen Grenzen. Die DDR im internationalen System 1949-1989. Munich: Oldenbourg, 2007.

Wölbern, Jan Philipp. Der Häftlingsfreikauf aus der DDR 1962/63-1989. Zwischen Menschenhandel und humanitären Aktionen. Göttingen: Vandenhoeck \& Ruprecht, 2014.

Wüstenhagen, Jana. "Blick durch den Vorhang”: Die SBZ/DDR und die Integration Westeuropas (1946-1972). Baden-Baden: Nomos, 2001.

Wüstenhagen, Jana. "RGW und EWG. Die DDR zwischen Ost- und Westintegration." In Die DDR und der Westen. Transnationale Beziehungen 1949-1989, edited by Ulrich Pfeil, 135-49. Berlin: Ch. Links, 2001.

Zatlin, Jonathan R. The currency of socialism: money and political culture in East Germany. Cambridge: Cambridge University Press, 2007. 